\title{
Peningkatan Sikap Ilmiah Matematika melalui Penerapan Model Pembelajaran Inkuiri Terbimbing di SD N 3 Banjar Jawa
}

\author{
Ni Luh Sadewi Widyani1 ${ }^{1}$ Desak Putu Parmiti² \\ 1 Jurusan Pendidikan Guru Sekolah Dasar, Universitas Pendidikan Ganesha, Singaraja, Indonesia \\ 2Jurusan Pendidikan Guru Sekolah Dasar, Universitas Pendidikan Ganesha, Singaraja, Indonesia
}

\section{A R T I C L E I N F 0}

Article history:

Received 19

November 2017

Received in revised form

6 Januari 2018

Accepted 12 Januari 2018

Available online 20

Februari 2018

Kata Kunci:

Inkuiri Terbimbing, benda konkret, sikap ilmiah

Keywords:

Guided Inquiry,

Concrete objects,

Scientific attitude

\section{A B S T R A K}

Penelitian inibertujuan untuk mengetahui peningkatan sikap ilmiah siswa kelas IV A Semester I di SD Negeri 3 Banjar Jawa, Tahun Pelajaran 2017/2018 pada mata pelajaran Matematika setelah penerapan model pembelajaran Inkuiri Terbimbing bermediakan benda konkret. Jenis penelitian ini adalah penelitian tindakan kelas yang dilaksanakan dalam dua siklus. Subyek penelitian adalah siswa IVA SD Negeri 3 Banjar Jawa, sebanyak 32 orang. Pengumpulan data dalam penelitian ini dilakukan dengan metode (1) angket/kuesioner, dan (2) observasi. Data yang didapatkan dari metode angket dianalisis dengan teknik analisis statistik deskriptif dan deskriptif kuantitatif. Hasil penelitian menunjukkan bahwa pada refleksi awal rata-rata persentase sikap ilmiah siswa pada mata pelajaran Matematika hanya mencapai $62,41 \%$ dan berada pada kategori kurang, meningkat pada siklus I menjadi $73,25 \%$ dan berada pada kategori cukup. Maka peningkatan sikap ilmiah siswa pada mata pelajaran Matematika sudah mencapai predikat yang telah ditetapkan. Dengan demikian model pembelajaran Inkuiri Terbimbing dengan bermediakan benda konkret dapat meningkatkan sikap ilmiah pada mata pelajaran Matematika siswa kelas IVA Semester I di SD Negeri 3 Banjar Jawa, Tahun Pelajaran $2017 / 2018$.

A B S T R A C T

This study was aimed 1) improving writing skill of the students of class $X A$ AKL at SMK Negeri 1 Singaraja by applying Mind Map and 2) finding out the response of the students to the application of Mind Map technique to improve writig skill. This study was classroom action research, conducted by the writer herself the subject were 34 students of class XA AKL at SMK Negeri 1 Singaraja. The study consisted of to cicle, it cicle had tp meetings with $3 \times 40$ minutes in each meeting. The data were collected through observation, questionaire, interview and test. The questionaire and test were used at the end every cycle. Based on the result of questionaire about the student's respons to Mind Map technique, their responsiveness were positive to the use of Mind Map technique in writing. This was shown by the data on the students' responses in the first cicle in which $47 \%$ responded positively and $41 \%$ responded very positively and increase and the second cicle to 50\% responded positively and $44 \%$ responded very positively. The main score in riting achievemet increase, the main in cicle one was 60 and ncrease to 74 in cicle.

Copyright (c) Universitas Pendidikan Ganesha. All rights reserved. 


\section{Pendahuluan}

Matematika merupakan bidang ilmu yang mempunyai kedudukan penting dalam kehidupan seharihari maupun dalam perkembangan ilmu pengetahuan dan teknologi. Perkembangan ilmu pengetahuan dan teknologi tidak lepas dari dukungan dan peranan Matematika. "Matematika berasal dari bahasa Yunani, yaitu Mathein atau Matheinein yang berarti mempelajari" Subarinah (dalam Dewi, 2011). "Kata Matematika diduga erat hubungannya dengan kata dari bahasa Sansekerta yaitu medha atau widya yang berarti kepandaian, ketahuan, atau intelegensia" Nasution (dalam Dewi, 2011).

Untuk menguasai dan menciptakan teknologi di masa depan diperlukan penguasaan Matematika yang kuat sejak dini. Penguasaan Matematika sejak dini bisa dimulai saat anak berada di sekolah dasar. Hal ini sebagaimana dimaksud Undang Undang No. 20 Tahun 2003 tentang Sistem Pendidikan Nasional (pasal 17 ayat 1) menyebutkan bahwa pada tingkat pendidikan dasar, kompetensi Matematika yang dikembangkan pada kelas I-VI sesuai dengan Kurikulum 2013 sebagaimana yang termuat dalam Permendikbud Nomor 21 Tahun 2016 tentang Standar Isi Sekolah Dasar dan Menengah, terdiri atas: (1) menunjukkan sikap positif bermatematika: logis, cermat dan teliti, jujur, bertanggung jawab, dan tidak mudah menyerah dalam menyelesaikan masalah, sebagai wujud implementasi kebiasaan dalam inkuiri dan eksplorasi matematika, (2) memiliki rasa ingin tahu, semangat belajar yang kontinu, percaya diri, dan ketertarikan pada matematika, yang terbentuk melalui pengalaman belajar, (3) memahami penjumlahan dan pengu-rangan bilangan asli, (4) mengelompokkan benda menurut tampilan bentuknya, bilangan asli dan pecahan sederhana, geometri dan pengukuran sederhana, statistika sederhana, penambahan dan pengurangan dari kumpulan objek, (5) mengidentifikasi seluruh dan bagian dalam kehidupan sehari- hari, Menggunakan gambar atau foto untuk menyatakan sebuah informasi dan menjawab pertanyaan mengenainya, (7) menyele-saikan masalah aritmetika sehari-hari sebagai penerapan pemahaman atas efek penambahan dan pengurangan, (8) Menyadari objek dapat dipandang sebagai kesatuan dari bagianbagiannya, (9) menggunakan model konkret dan simbolik atau strategi lain dalam penyelesaian masalah sehari-hari dan (10) bersikap terbuka menghadapi perbedaan sudut pandang.

Berdasarkan hal tersebut di atas, dapat dikatakan bahwa dalam pembelajaran Matematika, guru bukan hanya dituntut mengembangkan pengetahuan siswa, tetapi juga aspek keterampilan dan sikap siswa. Pada aspek keterampilan, pembelajaran Matematika diharapkan dapat meningkatkan keterampilan siswa dalam menyelesaikan masalah sehari-hari yang sesuai dengan pengetahuan yang diperoleh. Pada aspek sikap, pembelajaran diharapkan dapat mengembangkan sikap logis, cermat dan teliti, jujur, bertanggung jawab, dan tidak mudah menyerah dalam menyelesaikan masalah, memiliki rasa ingin tahu, semangat belajar yang kontinu, percaya diri, ketertarikan pada matematika, serta bersikap terbuka menghadapi perbedaan sudut pandang. Sikap-sikap tersebut dikenal dengan istilah sikap ilmiah siswa.

Menurut Bundu (2006), paling kurang terdapat empat jenis sikap yang relevan dengan sekolah dasar, yakni: (1) sikap terhadap pekerjaan di sekolah, (2) sikap terhadap diri mereka sebagai siswa, (3) sikap terhadap ilmu pengetahuan, dan (4) sikap terhadap objek dan kejadian di lingkungan sekitar. Keempat sikap tersebut akan membentuk sikap ilmiah yang memengaruhi keinginan seseorang merespon kepada orang lain, objek, atau peristiwa. Menurut Bundu (2006), orang yang berkecimpung dalam ilmu alamiah akan terbentuk sikap ilmiah yang antara lain ialah rasa ingin tahu, jujur, terbuka, berani, skeptis, serta tekun dan teliti. Sikap ilmiah dalam pembelajaran sangat diperlukan oleh siswa karena dapat memotivasi kegiatan belajarnya. Di dalam sikap ilmiah terdapat gambaran bagaimana siswa seharusnya bersikap dalam belajar, menanggapi suatu permasalahan, melaksanakan suatu tugas, dan mengembangkan diri. Hal tersebut tentunya sangat mempengaruhi hasil dari kegiatan belajar siswa ke arah yang positif. Melalui penanaman sikap ilmiah dalam belajar siswa memiliki kemungkinan untuk lebih dapat belajar memahami dan menemukan. Tingkat sikap ilmiah siswa dapat dilihat dari rasa keingintahuan yang sangat tinggi, memahami suatu konsep baru dengan kemampuannya tanpa ada kesulitan, kritis terhadap suatu permasalahan yang perlu dibuktikan kebenarannya, dan mengevaluasi kinerjanya sendiri Hal-hal inilah yang dapat membantu siswa belajar secara ilmiah, terstruktur, dan mandiri.

Sikap ingin tahu akan berbarengan dengan banyaknya pertanyaan yang akan dikemukakan pada anak, dan cenderung tidak bisa terpuaskan. Dari satu pertanyaan muncul pertanyaan berikutnya, dan seterusnya. Keingintahuan anak kecil dikategorikan sebagai belum matang "immature", spontan sesuai dengan dorongan kata hatinya sehingga mudah dirangsang dengan hal-hal baru.

Pada anak yang sudah mulai mencapai tingkat kematangan akan lebih banyak berkonsentrasi dan tidak sekadar mengikuti kata hatinya. Jumlah pertanyaan yang diajukan sudah mulai menurun tetapi cenderung lebih terarah dan beralasan. Sudah mulai mengembangkan pemikirannya dalam berinteraksi dengan pengalaman yang baru berdasarkan pengetahuan yang sudah dimiliki sebelumnya. Setelah mencapai kematangan maka akan terlihat pada keingintahuan untuk memahami dn mengerti apa yang 
dikerjakan. Dengan demikian, sikap ingin tahu menjadi satu bagian aktif dalam pembelajaran yang bermakna.

Kejujuran (honesty) dianggap berkaitan erat dengan respek terhadap fakta dan data serta jujur menyampaikan permasalahan ataupun kendala yang dihadapi ketika proses pembelajaran. Meskipun banyak ide-ide baru muncul dari hasil perenungan tetapi ide-ide tersebut tidak akan bertahan lama jika tidak didukung oleh alasan berupa data dan fakta yang tepat. Perasaan tajam siswa untuk tetap jujur dalam segala hal adalah merupakan landasan kuat untuk menghargai fakta dan data yang ditemukan. Mereka akan siap untuk saling memperlihatkan/menyajikan apa yang mereka temukan dan bukan disiapkan untuk menerima segala sesuatu sebagai kebenaran sebelum didukung oleh alasan yang dapat mereka terima. Sikap tidah mudah percaya (skeptis) dikembangkan dengan membiasakan siswa untuk tidak menerima saja sesuatu yang diajarkan tanpa bertanya. Siswa dibiasakan untuk melakukan percobaan ataupun mengumpulkan informasi terlebih dahulu tentang sesuatu yang dipelajari. Kegiatan percobaan ataupun mengumpulkan informasi tersebut dapat dilakukan dengan bekerja sama dalam kelompoknya.

Pada setiap kegiatan dalam pembelajaran, sikap tekun dan teliti sangat diperlukan karena sikap ini akan mendorong pada adanya refleksi tentang apa yang sudah dikerjakan, ide baru apa yang muncul dalam kegiatan tersebut, dan bagaimana kegiatan dapat dilakukan dengan lebih baik. Hasil refleksi kritis ini akan menyadarkan siswa tentang kemungkinan adanya beberapa alternatif yang dapat dilakukan dalam satu kegiatan. Selanjutnya, akan memunculkan sikap berani dalam menyampaikan pendapat berdasarkan data dan fakta yang ditemukan meskipun pendapat tersebut berbeda dengan pendapat teman lainnya.

Berdasarkan hasil observasi yang dilakukan terhadap pembelajaran Matematika yang dilaksanakan guru kelas IVA SD Negeri 3 Banjar Jawa, Kabupaten Buleleng, Provinsi Bali pada tanggal 08 September 2017 dengan materi pokok pembulatan bilangan cacah diperoleh data bahwa sebagian besar (84\%) hasil belajar Matematika siswa pada aspek pengetahuan dan keterampilan siswa telah mencapai KKM. Sebagai sekolah unggulan, rata-rata kemampuan kognitif dan psikomotor siswa SD Negeri 3 Banjar Jawa tergolong baik sehingga hanya beberapa orang siswa yang belum mencapai KKM. Berdasarkan hasil wawancara dengan wali kelas IVA, disampaikan bahwa bagi siswa yang belum mencapai KKM diberikan remedial berupa tugas tambahan atau penjelasan kembali sehingga pemahaman siswa dapat memenuhi standar. Begitu pula dengan keterampilan siswa dalam menyelesaikan masalah sehari-hari yang berkaitan dengan Matematika sudah tergolong baik karena konsep yang diperoleh sudah kuat. Salah satu permasalahan yang muncul dalam proses pembelajaran adalah belum maksimalnya pengembangan sikap siswa yakni sikap ilmiah siswa. Sikap ilmiah tersebut terdiri atas sikap ingin tahu, jujur (menghargai fakta atau data yang diperoleh), tidak mudah percaya (skeptis) atau kritis, tekun dan teliti, terbuka, berani dalam menyampaikan pendapat.

Berdasarkaan hasil analisis pengisian angket/kuesioner oleh siswa tentang tanggapan siswa terhadap pernyataan-pernyataan yang menunjukkan sikap ilmiah siswa diperoleh data bahwa sebagian besar sikap ilmiah siswa belum baik atau masih dalam kategori cukup. Data tersebut didukung dengan hasil observasi yang dilakukan dalam proses pembelajaran. Sebagian besar siswa tidak jujur dalam menyampaikan hasil percobaan/ pengamatan yang dilakukan karena takut data yang dilaporkan salah, masih sedikit siswa yang menanyakan hal-hal baru ketika diberi kesempatan bertanya oleh guru. Selain itu, kurangnya ketelitian siswa dalam menjawab pertanyaan juga ditunjukkan dengan adanya beberapa siswa/kelompok salah melakukan perhitungan ataupun pengukuran, serta sebagian besar siswa tidak percaya diri dalam menyampaikan pendapat serta berani memberikan masukan kepada teman. Beberapa siswa masih ragu-ragu untuk mengangkat tangan dan menyampaikan pendapat sehingga harus ditunjuk terlebih dahulu oleh guru.

Secara umum permasalahan yang ditemukan yakni rendahnya sikap ilmiah siswa pada mata pelajaran Matematika. Rendahnya sikap ilmiah siswa dikarenakan kurangnya keterlibatan siswa dalam proses pembelajaran sehingga siswa tidak memperoleh pengalaman dalam mengembangkan sikap ilmiahnya. Hal tersebut tentunya dapat memengaruhi hasil dari kegiatan belajar siswa untuk lebih dapat memahami dan menemukan konsep. Tujuan jangka panjang pembelajaran adalah meningkatkan kemampuan siswa agar ketika sudah meninggalkan sekolah, mereka mampu mengembangkan diri mereka sendiri dan mampu memecahkan masalah yang muncul. Selain itu mereka juga harus mampu mengantisipasi perkembangan ilmu pengetahuan dan teknologi yang semakin pesat. Oleh karena itu, selain dibekali dengan pengetahuan, pembelajaran seharusnya juga dirancang sedemikian rupa sehingga siswa memiliki kemampuan yang adaptif untuk mengatasi perubahan dengan mengembangkan sikap ilmiah pada dirinya dan belajar memecahkan masalah sejak dini. Rini (2015) Rendahnya sikap ilmiah ditunjukkan melalui banyaknya siswa yang mencontek saat ulangan, telat dalam pengumpulan tugas, sedikit siswa yang aktif mengajukan pertanyaan dan kurangnya kepercayaan diri saat guru menyuruh 
maju ke depan untuk menjawab soal. "Sikap ilmiah merupakan kecenderungan individu untuk bertindak atau berperilaku dalam memecahkan suatu masalah secara sistematis melalui langkah-langkah ilmiah" (Sukaesih:2011). Sikap ingin tahu (curiosity) termasuk kategori umum yang bisa mencakup sikap yang lainnya. Keingintahuan akan mendorong siswa untuk mendapatkan pengalaman baru dan belajar terhadap apa yang ada di sekitarnya.

Terdapat berbagai macam model pembelajaran inovatif yang dapat melibatkan partisipasi siswa. Salah satu model pembelajaran yang dapat memfasilitasi siswa untuk menemukan sendiri konsep yang dipelajari guna meningkatkan sikap ilmiah siswa adalah model pembelajaran Inkuiri atau penemuan. Model pembelajaran Inkuiri cocok untuk diterapkan dalam suatu pokok bahasan mata pelajaran misalnya pada mata pelajaran Matematika karena bukan hanya mengembangkan kemampuan kognitif tetapi juga dapat mengembangkan sikap siswa. Mempertimbangkan karakteristik siswa sekolah dasar yang belum mampu mandiri sepenuhnya dalam pembelajaran dan perlu adanya bimbingan untuk siswa dalam melakukan penemuan, maka model pembelajaran Inkuiri yang tepat dilaksanakan dalam proses pembelajaran di SD adalah model pembelajaran Inkuiri Terbimbing. Proses penemuan suatu konsep Matematika oleh siswa melalui kegiatan-kegiatan percobaan sesuai dengan petunjuk-petunjuk/bimbingan guru dapat mengembangkan sikap-sikap ilmiah siswa. Hal tersebut dikarenakan dalam proses percobaan, siswa dibimbing untuk menemukan sebuah konsep melalui cara atau metode-metode ilmiah yang tentunya dalam metode ilmiah tersebut menuntut sikap-sikap ilmiah siswa sehingga percobaan yang dilakukan berhasil dan menemukan kesimpulan yang diharapkan secara bersama-sama atas bimbingan guru.

Menurut hasil penelitian yang dilakukan Saraswati (2013), model pembelajaran Inkuiri Terbimbing dapat berpengaruh terhadap hasil belajar Matematika siswa karena siswa menemukan sendiri konsepkonsep yang dipelajari. Dalam penelitian tersebut juga dijabarkan bahwa model pembelajaran Inkuiri Terbimbing dapat menumbuhkan sikap objektif, jujur, hasrat ingin tahu, terbuka, dan sebagainya, yang pada akhirnya dapat mencapai kesimpulan yang disetujui bersama. Sikap-sikap yang dimaksud merupakan ciri-ciri sikap ilmiah. Model pembelajaran Inkuiri Terbimbing mendorong siswa untuk berpikir atas inisiatifnya sendiri, merumuskan hipotesisnya sendiri, siswa aktif dalam kegiatan belajar, siswa mampu menemukan konsep-konsep dan perkembangan berpikir ilmiah, serta siswa benar-benar dapat memahami suatu konsep dan rumus, sebab siswa mengalami sendiri proses untuk mendapatkan konsep atau rumus tersebut. Handayani (2015) "Perubahan paradigma pembelajaran, maka guru dituntut harus memiliki kreativitas dan inovasi dalam membuat perencanaan serta dalam melaksanakan pembelajaran sehingga sains sebagai produk dan sains sebagai proses bisa muncul dalam egiatan pembelajaran." Hermawati (2012) "Belajar dengan model inkuiri memanfaatkan keingintahuannya untuk mendapatkan suatu jawaban dari pertanyaan/masalah yang dimilikinya". "Inkuiri terbimbing digambarkan sebagai pendekatan yang berpusat pada siswa". (Maretasari :2012) "Model inkuiri terbimbing dapat dirancang penggunaannya oleh guru menurut kemampuan mereka atau menurut tingkat perkembangan intelektualnya" (Narni:2013) Juniati (2017). "Pada prinsipnya tujuan pengajaran inkuiri membantu siswa bagaimana merumuskan pertanyaan, mencari jawaban atau pemecahan untuk memuaskan keingintahuannya".

Selain menggunakan model pembelajaran Inkuiri Terbimbing, pemanfaatan benda-benda konkret sebagai media sangat membantu dalam pemerolehan konsep siswa. Belajar dengan menggunakan media konkret yang ada di sekitar siswa akan lebih bermakna dibandingkan dengan sumber yang asing bagi siswa. Hal tersebut sesuai dengan tingkat perkembangan intelektual usia sekolah dasar (7-11 tahun) yang berada pada tahap operasional konkret. Pembelajaran Matematika yang sangat dekat dengan siswa bukan hanya menekankan pada penguasaan kumpulan pengetahuan yang berupa fakta-fakta, konsep-konsep, atau prinsip-prinsip saja, tetapi juga merupakan suatu proses penemuan. Berdasarkan latar belakang permasalahan di atas, maka dipandang perlu untuk melakukan suatu tindakan. Tindakan yang dilakukan berupa penelitian dengan judul "Penerapan Model Pembelajaran Inkuiri Terbimbing Bermediakan Benda Konkret untuk Meningkatkan Sikap Ilmiah Matematika Siswa Kelas IVA Semester I Tahun Ajaran 2017/2018 di SD Negeri 3 Banjar Jawa". tujuan dilaksanakannya penelitian ini adalah untuk mengetahui peningkatan sikap ilmiah Matematika siswa kelas IVA semester I Tahun Ajaran 2017/2018 di SD Negeri 3 Banjar Jawa melalui penerapan model pembelajaran Inkuiri Terbimbing bermediakan benda konkret.

\section{Metode}

Jenis penelitian yang dilakukan di kelas IVA SD Negeri 3 Banjar Jawa adalah Penelitian Tindakan Kelas (PTK) atau dikenal dengan istilah Classroom Action Research. Penelitian Tindakan Kelas merupakan prosedur penelitian di kelas yang dirancang untuk menanggulangi masalah nyata yang dialami guru berkaitan dengan siswa di kelas itu (Santyasa, 2007). Penelitian ini merupakan Penelitian Tindakan Kelas 
dengan tindakan berupa penerapan model pembelajaran Inkuiri Terbimbing bermediakan benda konkret dalam pembelajaran Matematika. Penelitian ini bertujuan untuk meningkatkan sikap ilmiah siswa pada mata pelajaran Matematika di kelas IVA SD Negeri 3 Banjar Jawa dan sebagai upaya mengatasi permasalahan-permasalahan yang berhasil teridentifikasi di kelas tersebut.

Subjek penelitian ini adalah siswa kelas IVA semester I Tahun Ajaran 2017/2018 di SD Negeri 3 Banjar Jawa yang berjumlah 32 orang siswa yang terdiri atas 18 orang siswa perempuan dan 14 orang siswa laki-laki. Dari seluruh jumlah subjek penelitian tersebut secara umum siswa memiliki karakteristik yang berbeda antara satu dan yang lainnya, baik dari segi perhatiannya mengikuti pembelajaran, jenis kelamin, aktivitas dalam lingkungan sekolah, motivasi dan hasil belajar.

Penelitian ini mengikuti tahap-tahap penelitian tindakan kelas sebagaimana dikemukakan Kemmis dan Taggart (dalam Agung, 2005) yang masing-masing siklus terdiri atas empat tahap yaitu: (1) perencanaan tindakan, (2) pelaksanaan tindakan, (3) observasi atau evaluasi, serta (4) refleksi. Model penelitian yang menggambarkan beberapa siklus secara berkelanjutan dapat dilihat pada gambar 1 .

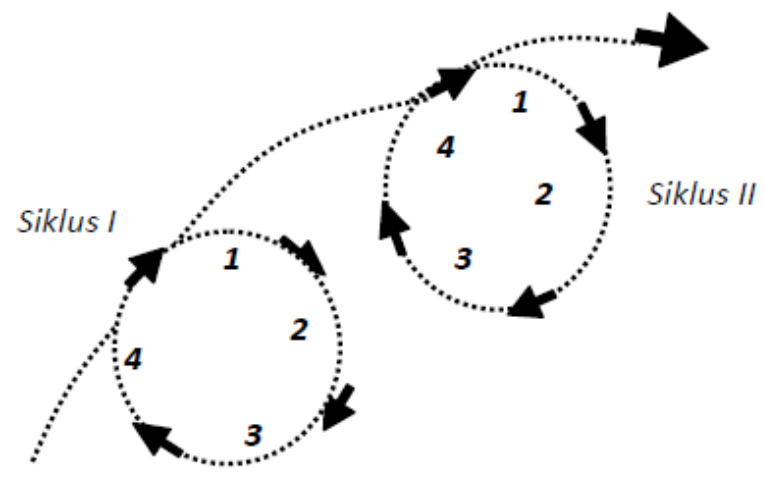

Gambar 1. Siklus PTKSumber: Kemmis dan Tanggart(dalam Agung, 2005)

Setiap siklus dilaksanakan dalam tiga kali pertemuan. Dua kali untuk kegiatan pembelajaran dan satu kali untuk tes akhir siklus. Peneliti berusaha untuk mengamati, merefleksi, dan mengevaluasi kegiatan pembelajaran yang berlangsung, setelah dilakukan refleksi biasanya muncul kesalahan sehingga tahap-tahap kegiatan tersebut berulang sampai suatu permasalahan dianggap teratasi. Pada pertemuan ketiga setiap siklus dilaksanakan pengumpulan data.

Pengumpulan data dilakukan disesuaikan dengan masalah yang dikaji yang berkaitan dengan penerapan model pembelajaran Inkuiri Terbimbing bermediakan benda konkret untuk meningkatkan sikap ilmiah pada mata pelajaran Matematika siswa kelas IVA semester I di SD Negeri 3 Banjar Jawa, Kecamatan Buleleng, Kabupaten Buleleng Tahun Pelajaran 2017/1218. Data yang dikumpulkan dalam penelitian terdiri atas data sikap ilmiah Matematika siswa. Metode yang digunakan untuk mengumpulkan data sikap ilmiah siswa adalah metode kuesioner dengan instrumen pengumpulan data berupa lembar kuesioner.

Sugiyono (2013), menyatakan bahwa angket merupakan seperangkat pertanyaan atau pernyataan secara tertulis untuk memperoleh informasi atau data dari responden. Lebih lanjut Sugiyono (2013), menyatakan bahwa skala sikap yang dapat digunakan dalam penelitian administrasi, pendidikan, dan sosial terdiri atas skala likert, skala guttman, rating scale, dan semantic deferential. Dalam penelitian ini bentuk kuesioner/angket yang digunakan adalah skala pengukuran skala likert. Agar butir-butir pernyataan kuesioner dapat mengukur sikap ilmiah yang diharapkan maka perlu dibuatkan kisi-kisi kuesioner. Kisi-kisi lembar kuesioner sikap ilmiah disusun berdasarkan komponen-komponen atau indikator-indikator sikap ilmiah yang terdiri atas sikap ingin tahu, jujur (menghargai fakta atau data yang diperoleh), tidak mudah percaya (skeptis) atau kritis, tekun dan teliti, terbuka, dan berani.

Setelah data dalam penelitian yang berupa data sikap ilmiah Matematika siswa terkumpul, maka dilakukan analisis data. Dengan menggunakan metode analisis statistik deskriptif dan metode analisis deskriptif kuantitatif. Metode analisis statistik deskriptif ialah suatu cara pengolahan data yang dilakukan dengan jalan menerapkan rumus-rumus statistik deskriptif seperti: distribusi frekuensi, grafik, angka rata-rata (Mean), median (Me), dan modus (Mo) untuk menggambarkan keadaan suatu objek tertentu sehingga diperoleh kesimpulan umum (Agung, 2005:60). Penerapan metode analisis statistik deskriptif dalam penelitian ini, data yang diperoleh dari hasil penelitian dianalisis dan disajikan ke dalam: a) tabel distribusi frekuensi, b) menghitung modus, c) menghitung median, d) menghitung angka rata-rata, dan e) menyajikan data. 
Metode analisis deskriptif kuantitatif adalah suatu cara pengolahan data yang dilakukan dengan jalan menyusun secara sistematis dalam bentuk angka-angka dan atau persentase mengenai keadaan suatu objek yang diteliti sehingga diperoleh kesimpulan umum (Agung, 2005:60). Dalam penelitian ini, metode analisis deskriptif kuantitatif ini digunakan untuk menentukan tingkat tinggi rendahnya sikap ilmiah Matematika siswa dengan penerapan model pembelajaran Inkuiri Terbimbing bermediakan benda konkret yang dikonversikan ke dalam Penilaian Acuan Patokan (PAP) skala lima. Peningkatan sikap ilmiah Matematika siswa ditentukan dengan membandingkan nilai yang diperoleh pada prasiklus, siklus I, dan siklus II. Tindakan dapat dikatakan berhasil apabila peningkatan sikap ilmiah Matematika mencapai predikat minimal sedang. Jika kriteria peningkatan sikap ilmiah Matematika siswa belum mencapai 0,30, maka penelitian dilanjutkan ke siklus berikutnya.

\section{Hasil dan Pembahasan}

Bedasarkan hasil penelitian siklus I maka mendapatkan hasil sebagai berikut. Rata-rata persentase sikap ilmiah siswa pada mata pelajaran Matematika pada siklus I sebesar 73,25\%, dan berada pada kategori sedang sehingga dapat dikatakan bahwa sikap ilmiah siswa IVA SD Negeri 3 Banjar Jawa belum mampu memenuhi kriteria yang ditetapkan yaitu berada pada kategori tinggi. Hasil tersebut diperkuat juga oleh rata-rata persentase sikap ilmiah siswa pada mata pelajaran Matematika pada pengumpulan data awal adalah 62,41\%. Setelah diberikan tindakan pada siklus I, rata-rata persentase sikap ilmiah siswa pada mata pelajaran Matematika meningkat menjadi 73,25\%, sehingga indeks peningkatan rata-rata persentase sikap ilmiah siswa adalah 0,29 , dan berada pada kategori rendah. Maka dari itu untuk meningkatkan sikap ilmiah siswa pada mata pelajaran Matematika diperlukan alternatif tindakan kelas yang lebih tepat dan efektif untuk meningkatkan kualitas pembelajaran siswa dengan melaksanakan siklus II.

Bedasarkan hasil penelitian siklus II maka mendapatkan hasil sebagai berikut. Rata-rata persentase sikap ilmiah siswa pada mata pelajaran Matematika pada siklus II sebesar 84,63\%, dan berada pada kategori tinggi. Hasil tersebut diperkuat juga oleh rata-rata persentase sikap ilmiah siswa pada mata pelajaran Matematika pada pengumpulan data siklus I adalah 73,25\%. Setelah diberikan tindakan pada siklus II, rata-rata persentase sikap ilmiah siswa pada mata pelajaran Matematika meningkat menjadi 84,63\%, sehingga indeks peningkatan rata-rata persentase sikap ilmiah siswa pada siklus II adalah 0,43, dan berada pada kategori sedang. Apabila dilihat dari refleksi awal, indeks peningkatan rata-rata peningkatan hasil belajar matematika pada siswa setelah pelaksanaan tindakan siklus II adalah 0,59, dan berada pada kategori sedang, Dengan mencermati data hasil kuesioner akhir siklus II, dapat dinyatakan bahwa terjadi peningkatan yang signifikan pada sikap ilmiah siswa kelas IVA pada mata pelajaran Matematika. Hasil yang dicapai pada siklus II merupakan hasil yang maksimal, dengan kata lain kegiatan pembelajaran berlangsung sesuai yang diharapkan yakni dapat meningkatkan sikap ilmiah siswa. Berdasarkan hal tersebut, maka penelitian ini dikatakan berhasil dan dapat dihentikan.

Ringkasan data indeks peningkatan mengenai sikap ilmiah siswa pada mata pelajaran Matematika selama penelitian dapat dilihat pada Tabel 1 berikut.

Tabel 1. Ringkasan Data Sikap Ilmiah Siswa pada Mata Pelajaran Matematika

\begin{tabular}{ccc}
\hline Tahap & $\begin{array}{c}\text { Indeks Peningkatan Rata-Rata Persentase } \\
\text { Sikap Ilmiah Siswa pada Mata Pelajaran } \\
\text { Matematika }\end{array}$ & Kategori \\
\hline Refleksi Awal menuju & 0,29 & Rendah \\
Siklus I & 0,43 & Sedang \\
$\begin{array}{c}\text { Siklus I menuju Siklus II } \\
\text { Refleksi Awal menuju } \\
\text { Siklus II }\end{array}$ & 0,59 & Sedang \\
\hline
\end{tabular}

Peningkatan rata-rata persentase sikap ilmiah siswa pada mata pelajaran Matematika dalam refleksi awal, siklus I, dan siklus II dapat digambarkan dalam bentuk grafik seperti pada Gambar 2. 


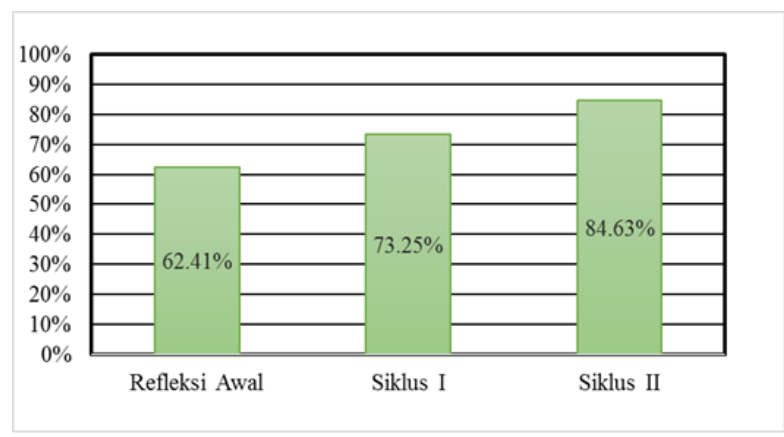

Gambar 2. Peningkatan Persentase Sikap Ilmiah Siswa

Berdasarkan hasil penelitian yang telah dilaksanakan dalam dua siklus, sikap ilmiah siswa kelas IVA di SD Negeri Banjar Jawa pada mata pelajaran Matematika semakin mengalami peningkatan. Sikap ilmiah siswa pada mata pelajaran Matematika mengalami peningkatan dari 62,41\% pada refleksi awal menjadi $73,25 \%$ pada siklus I dan pada siklus II meningkat menjadi 84,63\%. Indeks peningkatan sikap ilmiah siswa pada mata pelajaran Matematika dari refleksi awal menuju siklus I yaitu 0,29 termasuk pada kategori rendah dan dari siklus I menuju siklus II meningkat menjadi 0,43 termasuk pada kategori sedang, maka peningkatan sikap ilmiah siswa pada mata pelajaran Matematika sudah mencapai predikat yang telah ditetapkan yakni kategori sedang.

Peningkatan yang signifikan Sikap ilmiah siswa pada mata pelajaran Matematika disebabkan karena penerapan sintaks/langkah-langkah model pembelajaran Inkuiri Terbimbing serta menggunakan media konkret dalam proses pembelajaran. Menurut Suprihatiningrum (2013), langkah-langkah model pembelajaran Inkuiri Terbimbing terdiri atas orientasi pada masalah, merumuskan hipotesis, kegiatan penemuan, mempresentasikan hasil kegiatan, dan mengevaluasi kegiatan.

Langkah pertama yaitu siswa memahami permasalahan. Masalah yang disajikan adalah masalah yang berkaitan dengan materi yang akan dipelajari serta dikaitkan dengan kehidupan sehari-hari. Melalui petunjuk-petunjuk yang termuat dalam Lembar Kerja Siswa (LKS), siswa merumuskan masalah yang akan dipelajari kemudian memberikan pendapat serta menanyakan hal-hal yang belum dipahami terkait masalah yang disajikan dalam LKS. Berdasarkan pendapat-pendaat dari anggota kelompok, siswa kemudian merumuskan jawaban sementara dari permasalahan yang disajikan.

Untuk menguji jawaban sementara yang diajukan, siswa secara berkelompok melakukan kegiatankegiatan ilmiah. Kegiatan-kegiatan ilmiah tersebut dilakukan dengan melaksanakan kegiatan pengamatan, melakukan percobaan atau pengukuran terhadap benda-benda di sekitar atau benda konkret lainnya, serta menalar untuk menemukan suatu konsep dengan mengikuti langkah-langkah atau petunjuk yang disajikan dalam LKS. Dalam melakukan penemuan, siswa juga dilatih untuk secara aktif bertanya tentang beberapa hal yang belum jelas dari pernyataan atau pertanyaan yang termuat dalam LKS. Berdasarkan penemuan-penemuan yang dilakukan dari kegiatan ilmiah, siswa dengan percaya diri mempresentasikan/menyajikan hasil diskusinya/penemuannya di depan kelas. Presentasi dilakukan secara individu ataupun kelompok dengan menggunakan media konkret pada saat melakukan kegiatan penemuan. Berdasarkan hasil presentasi tersebut, siswa secara bersama-sama memeriksa kembali hasil kegiatan serta menarik kesimpulan dari kegiatan yang telah dilakukan. Kesimpulan tersebut adalah penemuan yang dilakukan siswa untuk selanjutnya merupakan konsep ataupun rumus yang akan digunakan dalam menyelesaikan permasalahan Matematika lainnya yang berhubungan dengan materi yang dipelajari.

Seluruh tahap dalam model pembelajaran Inkuiri Terbimbing tersebut dapat melatih siswa untuk mengembangkan sikap ilmiah siswa. Hasil penelitian sejalan dengan penelitian Santiasih (2013) yang menunjukkan bahwa, model pembelajaran Inkuiri Terbimbing mampu mengembangkan sikap ilmiah yang lebih baik dibandingkan model pembelajaran konvensional. Pembelajaran menggunakan model pembelajaran Inkuiri Terbimbing lebih baik dan efektif untuk menumbuhkan sikap ilmiah peserta didik. Siswa menjadi lebih termotivasi ketika belajar menemukan sesuatu oleh dirinya sendiri, daripada mendengarkan apa yang dikatakan pendidik. Lebih menekankan proses bagaimana siswa dapat menemukan suatu konsep Matematika melalui pengamatan ataupun percobaan berdasarkan petunjuk LKS dan bimbingan guru. Peserta didik lebih aktif dalam memanipulasi lingkungan dan media konkret lainnya. Hal tersebut akan dapat melatih dan mendorong sikap ilmiah siswa seperti rasa ingin tahu, jujur, terbuka, berani, skeptis, serta tekun dan teliti., dll. Keterlibatan siswa secara aktif baik fisik maupun mental dalam kegiatan penemuan, membawa pengaruh terhadap pembentukan pola tindakan siswa yang selalu didasarkan pada hal-hal yang bersifat ilmiah. 
Dengan memberikan objek baru kepada siswa dapat mengembangkan sikap ingin tahu siswa. Mendiskusikan hasil eksperimen akan memberikan kesempatan pada siswa untuk berpikir kritis. Hal tersebut dibuktikan dengan aktifnya siswa dalam mengemukakan pendapat serta mengajukan pertanyaan-pertanyaan yang belum mereka pahami ataupun diketahui. Pada saat siswa melakukan proses inkuiri, siswa dituntut untuk dapat bersikap jujur, terbuka, dan memiliki rasa tanggung jawab.

Dengan bimbingan guru, siswa diarahkan untuk berpikir secara sistematis, runtut, dan efektif untuk menyajikan laporan. Siswa menjadi aktif untuk mengingat kembali hasil percobaan dan mencari pengetahuan untuk menemukan jawaban dari permasalahan yang diberikan. Selain itu, bimbingan yang diberikan guru menjadi petunjuk bagi siswa yang mengalami kendala dalam penyusunan laporan untuk menghasilkan laporan yang baik.

Berdasarkan uraian di atas, secara umum telah mampu menjawab rumusan masalah. Penelitian ini dapat dikatakan berhasil, karena semua kriteria yang ditetapkan telah terpenuhi. Jadi sikap ilmiah siswa kelas IVA semester ganjil tahun pelajaran 2017/2018 SD Negeri 3 Banjar Jawa pada mata pelajaran Matematika meningkat melalui penerapan model pembelajaran Inkuiri Terbimbing serta penggunaan media konkret dalam pembelajaran.

4.

dan Saran

Simpulan

Berdasarkan hasil penelitian dan pembahasan yang telah diuraikan, dapat disimpulkan bahwa penerapan model pembelajaran Inkuiri Terbimbing serta menggunakan media konkret dalam pembelajaran dapat meningkatkan sikap ilmiah siswa kelas IVA SD Negeri 3 Banjar Jawa tahun pelajaran 2017/2018 pada mata pelajaran Matematika. Hal tersebut dapat dilihat dari semakin meningkatnya sikap ilmiah siswa pada mata pelajaran Matematika. Pada refleksi awal rata-rata persentase sikap ilmiah siswa pada mata pelajaran Matematika hanya mencapai $62,41 \%$ dan berada pada kategori rendah, meningkat pada siklus I menjadi $73,25 \%$ dan berada pada kategori cukup. Setelah dilaksanakan perbaikan tindakan pada siklus II, rata-rata persentase sikap ilmiah siswa pada mata pelajaran Matematika semakin meningkat mencapai $84,63 \%$ dan berada pada kategori baik. Indeks peningkatan sikap ilmiah siswa pada mata pelajaran Matematika dari refleksi awal menuju siklus I yaitu 0,29 termasuk pada kategori rendah dan dari siklus I menuju siklus II meningkat menjadi 0,43 termasuk pada kategori sedang, maka peningkatan sikap ilmiah siswa pada mata pelajaran Matematika sudah mencapai predikat yang telah ditetapkan.

Terkait dengan uraian dan simpulan diatas, maka dapat disampaikan beberapa saran sebagai berikut. (1) Siswa-siswa di sekolah dasar agar lebih aktif dalam mengikuti pembelajaran dan terus mengembangkan pemahaman, keterampilan serta pengetahuan yang telah dimiliki melalui kegiatankegiatan ilmiah untuk menemukan konsep-konsep dalam proses pembelajaran matematika. (2) Guru disarankan agarmemberikan pengalaman, kesempatan, dan fasilitas serta bimbingan yang optimal kepada siswa berlatih agar lebih aktif dalam menemukan konsepmelalui kegiatan-kegiatan ilmiah sehingga dapat mengembangkan sikap ilmiah siswa. (3) Sekolah yang menemukan permasalahan yang sama dengan penelitian iniagar menggunakan model pembelajaran Inkuiri Terbimbing serta menggunakan media konkret dalam pembelajaran. Selain berguna bagi siswa untuk menemukan konsep-konsep Matematika, pembelajaran dengan model pembelajaran tersebut juga dapat mengembangkan sikap-sikap ilmiah siswa. dan bagi (4) Peneliti lain yang berminat untuk mengadakan penelitian lebih lanjut tentang model pembelajaran Inkuiri Terbimbing serta menggunakan media konkret dalam pembelajaran agar memperhatikan kendala-kendala yang dialami, diantaranya masalah waktu pelaksanaan penelitian dan biaya yang digunakan dalam penelitian ini sebagai bahan pertimbangan untuk perbaikan dan penyempurnaan penelitian yang akan dilaksanakan.

\section{Daftar Rujukan}

Agung, A. A. G. 2005. Metodologi Penelitian Pendidikan. Singaraja: Fakultas Ilmu Pendidikan Institut Keguruan dan Keilmuan Negeri Singaraja.

Anggraini , Rini . 2015. "Penerapan Model Pembelajaran Group Investigation (GI) Menggunakan Local Material Berbasis Lesson Study Untuk Meningkatkan Kemampuan Berpikir Kritis, Motivasi Dan Sikap Ilmiah Siswa Kelas X Sman 1 Mojo Kediri” . FKIP-Biologi Simki.Unpkediri.Ac.Id

Bundu, P. 2006. Penilaian Keterampilan Proses dan Sikap Ilmiah dalam Pembelajaran Sains Sekolah Dasar. Jakarta: Departemen Pendidikan Nasional Direktorat Jenderal Pendidikan Tinggi Direktorat. 
Dewi , Narni Lestari, Nyoman Dantes, I Wayan Sadia."2013". Pengaruh Model Pembelajaran Inkuiri Terbimbing Terhadap Sikap Ilmiah Dan Hasil Belajar IPA". e-Journal Program Pascasarjana Universitas Pendidikan Ganesha Jurusan Pendidikan Dasar (Volume 3 Tahun 2013)

Hermawati, Ni Wayan Manik.2012. "Pengaruh Model Pembelajaran Inkuiri Terhadap Penguasaan Konsep Biologi Dan Sikap Ilmiah Siswa SMA Ditinjau Dari Minat Belajar Siswa”. Universitas Pendidikan Ganesha

Juniati, Ni Wayan dan I Wayan Widiana. (2017). "Penerapan Model Pembelajaran Inkuiri Untuk Meningkatkan Hasil $\quad$ Belajar IPA". Jurnal Ilmiah Sekolah Dasar. Vol.1 $\quad$ (1) pp. 20-29 Undiksha

Maretasari E., B. Subali, Hartono.2012. "Penerapan Model Pembelajaran Berbasis Laboratorium Untuk Meiningkatkan Hasil Belajar Dan Sikap Ilmiah Siswa. UPEJ (1) 2012 Physics Education. Jurusan Fisika, Fakultas Matematika dan Ilmu Pengetahuan Alam Universtas Negeri Semarang, Semarang, Indonesia

Rustaman, Nuryani Y. 2005. “Perkembangan Penelitian Pembelajaran Inkuiri dalam Pendidikan Sains”. FPMIPA UPI

Santiasih, N. L. 2013. Pengaruh Model Pembelajaran Inkuiri Terbimbing terhadap Sikap Ilmiah dan Hasil Belajar IPA Siswa Kelas V SD No. 1 Kerobokan Kecamatan Kuta Utara Kabupaten Badung Tahun Ajaran 2013/2014. Skripsi Program Studi PGSD, FIP, Universitas Pendidikan Ganesha.

Santyasa, W. 2007. Metodologi Penelitian Tindakan Kelas. Makalah disajikan dalam Workshop tentang Penelitian Tindakan Kelas (PTK) bagi Para Guru SMP 2 dan 5 Nusa Penida Klungkung, pada tanggal 30 Nopember s.d 1 Desember 2007.

Saraswati, L. Nym. 2013. Pengaruh Model Pembelajaran Inkuiri Terbimbing terhadap Hasil Belajar Matematika Siswa Kelas III SD di Gugus I Kecamatan Buleleng. Skripsi Program Studi PGSD, FIP, Universitas Pendidikan Ganesha.

Sugiyono. 2013. Metode Penelitian Pendidikan. Bandung: Alfa Beta

Sukaesih, Sri. 2011. "Analisis Sikap Ilmiah Dan Tanggapan Mahasiswa Terhadap Penerapan Model Pembelajaran Berbasis Praktikum Jurnal Penelitian Pendidikan Vol 28 Nomor 1 Tahun 2011 77". Biology Deparment Science And Mathematic Faculty Semarang State University

Sumintono, Bambang. 2014. Pembelajaran Sains, Pengembangan Ketrampilan sains dan sikap ilmiah dalam meningkatkan kompetensi guru". https://www.researchgate.net/publication/232710209

Suprihatiningrum, J. 2013. Strategi Pembelajaran (Teori dan Aplikasi). Yogyakarta: Ar-Ruzz Media.

Trisna , I Dw A. Handayani, I Wayan Karyasa, I Nyoman Suardana. 2015. "Komparasi Peningkatan Pemahaman Konsep dan Sikap Ilmiah Siswa SMA yang dibelajarkan dengan Model Pembelajaran Problem Based Learning dan Project Based Learning". E- Journal Program Pascasarjana Universitas Pendidikan Ganesha Program Studi Pendidikan IPA (Volume 5 Tahun 2015).

Widiana, I Wayan. 2016. Pengembangan Asesmen Proyek Dalam Pembelajaran IPA di Sekolah Dasar. Jurnal Pendidikan Indonesia Vol 6.No 2 tahun 2016. (http://ejournal.undiksha.ac.id/ index.php/JPI/article/view/8154). 